\title{
ASPEKTY PRAWNE KONTAKTÓW Z DZIECKIEM
}

\section{CEL ROZWAŻAŃ}

Artykuł ${ }^{1}$ stanowi próbę aktualizacji wiedzy na temat stanu prawnego dotyczącego instytucji kontaktów z dzieckiem po nowelizacji Kodeksu rodzinnego i opiekuńczego z $2008 \mathrm{r}^{2}{ }^{2}$ Przeprowadzona analiza pozwoli określić charakter prawny instytucji oraz sformułować koncepcje zmian legislacyjnych odnoszacych się w głównej mierze do relacji rodzicielskiej. Dopiero bowiem wobec jasnego określenia charakteru prawnego prawa i obowiązu rodziców i dzieci, a także jego źródła, „odpowiednio” można stosować te zasady wobec innych osób uprawnionych do kontaktu. Struktura relacji z rodzeństwem czy dziadkami jest na tyle obszerna, że jej szczegółowa analiza przekraczałaby ramy niniejszych rozważań, stąd wyłączną uwagę poświęcono kontaktowi rodziców z dzieckiem. Niewątpliwie jest to więź zasługująca na najsilniejsza ochronę - to ona stanowi genezę instytucji kontaktów i to ona jest niezbędna do prawidłowego rozwoju dziecka. Relacje z rodzeństwem, dziadkami ${ }^{3}$ oraz innymi osobami - choć wartościowe - nie sa niezastapione w kształtowaniu osobowości. Nie wszystkie spośród dzieci mają rodzeństwo czy żyjących dziadków, co nawet w przypadku rodziny małej, liczącej trzy osoby, nie wpłynie negatywnie na rozwój emocjonalny dziecka. Inaczej natomiast jest wobec silnie odczuwalnego braku jednego z rodziców, co zostało poparte wyczerpująca już do tej pory literatura naukowa ${ }^{4}$, dotyczaca syndromu oddzielenia dziecka od rodziców - tzw. PAS (parental alientation syndrom), który nie posiada swojego odpowiednika w przypadku izolacji od innych niż rodzice członków rodziny.

${ }^{1}$ Opracowanie stanowi próbę syntetycznego omówienia najważniejszych tez pracy doktorskiej Prawo i obowiqzek kontaktu z dzieckiem, UAM, Poznań 2018 (maszynopis).

${ }^{2}$ Ustawa o zmianie ustawy - Kodeks rodzinny i opiekuńczy oraz niektórych innych ustaw z 12 sierpnia 2008 r., druk nr 888.

${ }^{3}$ Por. J. Haberko, Dziadkowie-wnuki, osobista więź prawnorodzinna i relacja prawnospadkowa, „Ruch Prawniczy, Ekonomiczny i Socjologiczny” 74, 2012, z. 3, s. 156.

${ }^{4}$ Por. A. Czerderecka, Potrzeba profesjonalnej dyskusji na temat PAS, „Psychiatria Polska” 44, 2010, nr 1 s. 13-26; eadem, Rozwód a rywalizacja o opiekę nad dziećmi, Warszawa 2010; T. Justyński, Parental Alienation Syndrome (PAS) w świetle prawa i judykatury niemieckiej, w: Ksiega Jubileuszowa Profesora Tadeusza Smyczyńskiego, Toruń 2008, s. 373-382. 


\section{RODZINNOPRAWNY CHARAKTER INSTYTUCJI}

Nadany przez ustawodawcę kształt prawa i obowiązku kontaktu mógłby sugerować charakter zobowiązaniowy instytucji. Prawu dziecka odpowiada obowiązek rodziców i na odwrót. Jednakże w tym przypadku interes stron relacji pokrywa się, a nie jest jak w typowym stosunku zobowiązaniowym przeciwległy. W schemacie dłużnik-wierzyciel w umowach wzajemnych oba podmioty, dazżąc do wypełnienia długu i wierzytelności, a więc zobowiązania dłużnika i zobowiązania wierzyciela ${ }^{5}$, kierują się własnymi interesami. W stosunku rodzice-dzieci zachodzi niezwykła właściwość polegająca na pokrywaniu się interesów obu stron. Rodzice bowiem, realizując interes dziecka, realizują jednocześnie swój własny interes, są one zatem tożsame i zmierzają w tym samym kierunku, którego celem jest dobro dziecka. W tym aspekcie jest to już zbliżona relacja do zobowiązania wynikającego z umowy, którego celem jest $\mathrm{z}$ kolei zaspokojenie interesu wierzyciela ${ }^{6}$. Tymczasem mimo że interes rodziców zmierza w jednakowym kierunku co interes dziecka, rodzice w większym stopniu realizują swój obowiazek, który odpowiada interesowi dziecka. Nie dzieje się tak jednak po mi mo wspomnianej konstatacji, lecz bardziej jako konsekwencja tego stanu rzeczy. Obowiązek rodziców odpowiada interesowi dziecka nie dlatego, że zwrócony jest w tym jednakowym kierunku, lecz dlatego, że obowiązek ten z natury rzeczy zmierza w tym samym kierunku.

Stąd pomimo słuszności wprowadzenia obowiązku kontaktu po stronie dziecka, przypisywanie charakteru zobowiązaniowego relacjom rodzicielskim należy czynić z niezwykłą ostrożnościa, zwłaszcza że sens obowiązku polega nie tylko na formułowaniu nakazu, lecz także uzmysłowieniu obu stronom kontaktu, że utrzymywanie go nie jest dobrowolną decyzja, której można się zrzec. Dlatego charakter kontaktu, pomimo ustawowego obustronnego prawa i obowiązku, jest jedynie zbliżony do charakteru zobowiązaniowego występującego w prawie cywilnym. Konsekwencją tego jest nie tylko stwierdzenie, że instytucja ta ma charakter rodzinnoprawny, ale również że taki charakter ma sankcja z tytułu niewykonywania prawa i obowiązku kontaktu.

\section{ZMIENNOŚĆ PRAWA I OBOWIĄZKU KONTAKTU}

Niniejsza analiza prowadzić może do spojrzenia na kontakt jako swoista „relację zmienną" (w pewnym sensie „obrotową). Oznaczać by to miało, że początkowo to rodzice mają większy obowiązek, później zaś prawo, a następnie to dziecko ma w większym stopniu prawo, a później obowiązek kontaktu. Jak zresztą zauważono, dzieci sa grupa społeczna, która ma szerokie prawa w porównaniu ze szczuplejszym zakresem obowiązków, przy czym „są okresy

${ }^{5}$ P. Machnikowski, w: System prawa prywatnego, t. 5: Prawo zobowiazań - część ogólna, Warszawa 2006, s. 125.

${ }^{6}$ Por. J. Sauk, Granice obowiqzków, Toruń 1967, s. 10-11. 
w życiu człowieka, w których ma on wyraźnie przewagę praw w porównaniu z ciążącymi na niej w tym czasie obowiązkami”7. Dla zobrazowania tej koncepcji odwołać się można do roszczenia związanego z prawem i obowiązkiem alimentowania, które uaktualnia się w chwili powstania potrzeby i adekwatnie do niej się kończy ${ }^{8}$. Charakterystyczne jest więc, że przez cały okres jego trwania dostrzec można pewien mechanizm nasilania i wygasania. Istnieje on w formie zaspokajania potrzeb rodziny, w efekcie przekształcajac się w obowiązek alimentacyjny z chwilą jej rozpadu. Co istotniejsze zaś, stanowi relację, która najpierw skierowana jest wobec dziecka, aby co do zasady w przyszłości „obrócić się” wobec rodziców, a więc w ramach tych samych stron podmiotowych - co stanowi o wspomnianej „zmienności” (względnie „obrotowości”). Podążając w rozważaniach o krok dalej, z obowiązkiem alimentacyjnym związana jest zasada równej stopy życiowej rodziców i dzieci ${ }^{9}$, istniejąca również w rodzinie pełnej, jednakże jako roszczenie aktualizuje się dopiero w chwili jej rozpadu. Podobnie w przypadku instytucji kontaktów w początkowej fazie życia dziecka jego prawu towarzyszy przede wszystkim obowiązek rodziców, z kolei w dalszej fazie życia rodziców wraz ze stopniowym spadkiem obowiązu po ich stronie, adekwatnie wzrasta on po stronie dorosłego dziecka i rośnie proporcjonalnie do starzenia się rodziców ${ }^{10}$. Ponadto nie jest to powinność ekwiwalentna, a zatem bez znaczenia dla realizacji obowiązku dziecka pozostaje sposób, w jaki rodzice wywiązywali się z obowiązku kontaktu wobec niego.

Podstawę do powyższej refleksji stanowi teza, że prawo i obowiązek po osiagnięciu pełnoletności trwa ${ }^{11}$. Stanowisko takie jest konsekwencją odmiennego uregulowania pokrewnej instytucji władzy rodzicielskiej, w której ustawodawca wskazał granicę końcową w art. 92 k.r.o., czego nie uczynił w art. 113 k.r.o. Przyjęcie trwania prawa i obowiązku kontaktów pomimo osiagnięcia pełnoletności jest uzasadnione szczególnie w świetle dwojakiego znaczenia pojęcia „dziecko”, którym posługuje się ustawodawca, tj. jako osoby małoletniej oraz jako krewnego I stopnia, niezależnie od wieku. Przykłady przepisów, w których pojęcie to oznacza pochodzenie jednej osoby od drugiej, to m.in. art. $61^{9}$ k.r.o. stanowiący, że matką dziecka jest kobieta, która dziecko urodziła, nawiąuje on bowiem do stanu cywilnego dziecka w sensie jego przynależności rodzinnej, którego to statusu wynikającego z więzów krwi dziecko nie traci przez osiagnięcie pełnoletności ${ }^{12}$; art. 87 k.r.o., w któ-

7 M. Balcerek, Prawa dziecka, Warszawa 1986, s. 289.

${ }^{8}$ Por. szerzej J. Haberko, Charakter prawny relacji rodzice-dorosłe dzieci w kontekście zobowiazań alimentacyjnych rodziców, „Ruch Prawniczy, Ekonomiczny i Socjologiczny” 77, 2015, z. 4, s. 41-55; J. Zajączkowska, Bezskuteczność uznania dziecka jest łatwiejsza, „Rzeczpospolita” z 17 czerwca 2011 r.

9 Por. szerzej A. Szlęzak, Zasada równej stopy życiowej w prawie rodzinnym, „Ruch Prawniczy, Ekonomiczny i Socjologiczny" 47, 1985, nr 1, s. 37-50.

10 Podobnie J. Gajda, który w odniesieniu do obowiązków zauważa, że inaczej rozkładać się będą „akcenty” wobec dziecka małoletniego, a inaczej wobec pełnoletniego, w szczególności, że co do zasady w pierwszym przypadku przeważać będą obowiązki - idem, w: K. Pietrzykowski (red.), Kodeks rodzinny i opiekuńczy, Warszawa 2015, s. 693.

11 Por. ibidem.

12 Ibidem, s. 694. 
rym ustawodawca ustanawia obowiązek wzajemnego szacunku i wspierania się, a przez sformułowanie „rodzice i dzieci” odnosi je również do dzieci pełnoletnich. W art. 91 § 1 i 2 k.r.o. również nie bez znaczenia jest brak określenia wieku dziecka, a także wykładnia systemowa, tj. umieszczenie przepisu poza oddziałem 2 poświęconym władzy rodzicielskiej. Przemawia to bowiem za traktowaniem obowiązków dziecka przyczyniania się do pokrywania kosztów rodziny oraz pomagania we wspólnym gospodarstwie określonych w omawianym przepisie jako niezależnych od sprawowania władzy rodzicielskiej ${ }^{13}$. W konsekwencji, pomimo używanego w $§ 1$ i 2 art. 91 k.r.o. pojęcia dziecka, uznaje się, że obowiązek ten nie zależy od tego, czy dziecko jest małoletnie czy pełnoletnie ${ }^{14}$.

Mając na uwadze powyższe rozważania oraz wspomniane analogiczne przykłady - teza, że prawo i obowiązek kontaktu nie wygasa wraz z osiagnięciem pełnoletności, jest uzasadniona. Przy czym nie przeczy temu okoliczność, że prawo i obowiązek nie są już dłużej egzekwowalne w takiej postaci, jak ją definiuje oddział 3 rozdział II k.r.o.

\section{ZAKRES PRAWA DO KONTAKTU}

Dotychczas dominowało ujęcie przedmiotowe małoletniego jako osoby biernie „odwiedzanej” przez jedno z rodziców, mające roszczenie do domagania się uregulowania kontaktów. Dlatego pomimo niezaprzeczalnego istnienia prawa dziecka do kontaktu z jednym z rodziców literalne sprecyzowanie go potwierdza i podkreśla jego podmiotowość, tym samym umożliwia domaganie się przez dziecko przysługującego mu kontaktu, co dodatkowo wzmocnione zostało prawem do własnego stanowiska oraz instytucją wysłuchania małoletniego. Dziecko może nie chcieć korzystać ze swego prawa do kontaktu (pozostając pod wpływem drugiego z rodziców), jednakże przyznanie wprost tego prawa może również przyczynić się do łatwiejszego zignorowania przez dziecko tego typu nacisków, dzięki świadomości, iż jest to prawo podmiotowe przysługujące mu niezależnie od stanowiska bądź opinii jednego z rodziców z nim zamieszkującego $^{15}$. Jednocześnie jednak nasuwa się refleksja wskazująca na niemożność dochodzenia roszczenia przez dziecko. Jak zauważono w piśmiennictwie kanadyjskim ${ }^{16}$, pomimo że istnienie prawa dziecka do kontaktu nie budzi wątpliwości, w praktyce to jedno z rodziców równolegle je posiadajaccy prawo to egzekwuje. Tym samym prawo dziecka do kontaktu staje się w efekcie prawem do kontaktu tego z rodziców.

13 J. Słyk, w: G. Jędrejek (red.), Prawo rodzinne, Warszawa 2015, s. 589.

14 E. Trybulska-Skoczelas, w: J. Wierciński (red.), Kodeks rodzinny i opiekuńczy. Komentarz, Warszawa 2014, s. 694.

15 T. Justyński, Prawo do kontaktów z dzieckiem w prawie polskim i obcym, Warszawa 2011, s. 80 .

${ }^{16}$ F. Kelly, Enforcing a parent/child relationship at all costs? Supervised access orders in the Canadian courts, „Osgoode Hall Law Journal” 49(2), 2012, s. 305-306. 
Należy uznać istnienie roszczenia płynącego z prawa podmiotowego dziecka i mimo że dziecko nie może występować z roszczeniem procesowym, to jeśli zwróciłoby się do sądu - ten powinien z urzędu na sygnał otrzymany od dziecka zbadać prawidłowość realizowania kontaktów ${ }^{17}$. Można zatem mówić o faktycznym istnieniu roszczenia po stronie dziecka, jednakże o szczególnym, rodzinnoprawnym charakterze. W dalszym ciagu aktualny zatem pozostaje wniosek de lege ferenda o umożliwieniu wystapienia przez dziecko z własnym roszczeniem w dotyczącym go postępowaniu, w szczególności o utrzymywanie kontaktu ${ }^{18}$.

Czyniąc uwagi prawnoporównawcze wystarczy wskazać na funkcjonowanie instytucji niezależnego adwokata dziecka m.in. w Wielkiej Brytanii, USA czy Australii. W pierwszym ze wspomnianych krajów instytucja o nazwie National Advocacy Meic dzięki całodobowej infolinii pozwala dzieciom na bezpośrednia rozmowę $\mathrm{z}$ adwokatem ${ }^{19}$. Istnieją również organizacje ${ }^{20}$, które gwarantuja poufna, bezpłatną rozmowę, zapewniając anonimowość przez nierejestrowanie numerów na zestawieniach z wyciagów telefonicznych. Z kolei w USA funkcjonuje instytucja adwokata o nazwie attorney for the minor child (AMC) ${ }^{21}$, którego sąd może powołać z urzędu, nawet wbrew rodzicom. Jego rola polega na przedstawieniu interesów dziecka w sądzie po wcześniejszych spotkaniach z dzieckiem, z którym pozostaje w kontakcie aż do zakończenia postępowania. Jeszcze wyraźniejszy przykład stanowi instytucja niezależnego prawnika dziecięcego (independent children's lawyer, ICL) w Australii. Akt prawa rodzinnego z 1975 r..$^{22}$ w sekcji 68L pkt 4 ppkt b stanowi, że sąd może zarządzić jego ustanowienie z własnej inicjatywy lub na wniosek samego dziecka. Wytyczne dla niezależnego prawnika dziecięcego z $2013 \mathrm{r} .{ }^{23} \mathrm{w}$ pkt 5 wskazuja, że dziecko ma prawo do ustanowienia profesjonalnej relacji z prawnikiem.

\section{OBLIGATORYJNOŚĆ KONTAKTU JAKO WYNIK UREGULOWAŃ PRAWNYCH}

Wraz z nałożeniem na dziecko obowiązku kontaktu pojawiły się przeciwne takiemu rozwiązaniu stanowiska. Pierwsze - wyrażające obawę, że przymuszanie dziecka przyniesie odwrotny od zamierzonego skutek i będzie niezgod-

17 T. Sokołowski, w: H. Dolecki, T. Sokołowski (red.), Kodeks rodzinny i opiekuńczy. Komentarz, Warszawa 2010, s. 668.

${ }^{18}$ Zob. Wnioski $i$ postulaty, w: M. Grudzińska, Kontakty $z$ dzieckiem: sqdowe ustalenie, orzecznictwo, wzory, Warszawa 2000.

${ }^{19}$ Zob. <http://www.childreninwales.org.uk/our-work/advocacy/meic/> [dostęp: 5.04.2016].

${ }^{20}$ Zob.np.<https://www.meiccymru.org, http://www.rctcbc.gov.uk/EN/Resident/ChildrenandFamilies/Gettingyourvoiceheard/Gettingyourvoiceheard.aspx> [dostęp: 5.04.2016].

${ }^{21}$ Guardian ad litem or attorney for minor child in family matters, <https://www.jud.ct.gov/ Publications/FM224.pdf> [dostęp: 5.4.2016].

${ }^{22}$ Zob. <http://www.austlii.edu.au/au/legis/cth/consol_act/fla1975114/s68l.html> [dostęp: 5.04.2016].

${ }^{23}$ Guidelines for Independent Children's Lawyers, <http://www.legalaid.wa.gov.au> [dostęp: 5.04.2016]. 
ne z jego dobrem, czego konsekwencją stanie się przedkładanie dobra rodziców nad dobro dziecka, co byłoby sprzeczne z idea całej ustawy ${ }^{24}$. Drugie - wykazujące, że uregulowanie obowiązku kontaktu powiela obowiązki wynikające z art. 87 k.r.o. ${ }^{25}$ Tymczasem trudno podzielić krytykę dotycząca obowiązku kontaktu jako superfluum wobec obowiązu wspierania i szacunku ${ }^{26}$. Podążając taką wykładnia, podobnie należałoby postrzegać obowiązki wynikające ze wsparcia materialnego, jak obowiązek z art. 24 czy 133 k.r.o., wobec interpretacji art. 87 k.r.o. umożliwiającej również wyprowadzenie z niej obowiązku utrzymania i przyczyniania się do współuczestniczenia w kosztach rodziny ${ }^{27}$. Gdyby przychylić się do takiego ujęcia, wówczas wiele $\mathrm{z}$ istniejących $\mathrm{w}$ prawie rodzinnym przepisów obligujacych do pewnych zachowań lub nakładających obowiązki można by uznać za zbędne. Ponadto odpierając zarzuty dotyczące sformułowania obowiąku w art. 113 k.r.o., należy podkreślić, że nie tylko $\mathrm{w}$ prawie polskim, ale również $\mathrm{w}$ doktrynie amerykańskiej, zauważa się, że „prawo do wizyt” w odróżnieniu od samego uprawnienia pociaga za sobą również istnienie obowiązku ${ }^{28}$.

Dziecko, ze względu na ograniczoną możliwość zaspokajania swoich potrzeb, musi pozostawać pod pieczą rodziców. Dlatego też należy założyć, że wymaganie przez nich realizowania obowiązku kontaktu, nawet jeżeli pociaga za sobą ryzyko początkowego przymuszania dziecka, odbywa się w zgodzie z jego dobrem. Wystarczy przytoczyć przykład obowiązku szkolnego, który wiąże się niejednokrotnie z koniecznością przymuszenia dziecka do jego realizacji. Taki sam wniosek płynie $\mathrm{z}$ analizy istnienia obowiązku ochrony zdrowia dziecka, z którym nieodłącznie związane jest ingerowanie przez rodziców w wolność dziecka, być może sprzeczną z jego wola, lecz zgodną z jego dobrem $^{29}$. Pomimo ożywionej polemiki dotyczącej obowiązu kontaktu nie stanowi to istoty owej instytucji. Sens obowiązku polega nie tylko na formułowaniu nakazu, ale też uzmysłowieniu obu stronom kontaktu, że utrzymywanie go nie jest dobrowolną decyzja, której można się zrzec.

\section{PRZESZKODY W RELACJI RODZICE-DZIECKO}

Skoro polski ustawodawca zmierza do ukształtowania modelu zachowań, które uznać można za wzór relacji, do jakiego należy dążýc po rozpadzie rodziny, to niezbędne jest sformułowanie odpowiadających sobie obowiązków.

${ }^{24}$ W. Stojanowska, w: eadem, M. Kosek (red.), Nowelizacja prawa rodzinnego na podstawie ustaw z 6 listopada 2008 i 10 czerwca 2010. Analiza. Wykładnia. Komentarz, Warszawa 2011, s. 267.

${ }^{25}$ J. Gajda, op. cit., s. 960.

${ }_{26}$ Tak W. Stojanowska, op. cit., s. 266.

27 Por. A. Sylwestrzak, Obowiazki dziecka wobec rodziców, „Ruch Prawniczy, Ekonomiczny i Socjologiczny” 63, 2001, z. 3, s. 61 i n.

28 A. Blecher-Prigat, Rethinking visitation: from a parental to a relational right, „Duke Journal of Gender Law \& Policy" 16, 2009, s. 2-3 i powołana tam literatura.

${ }_{29}$ Por. T. Sokołowski, Władza rodzicielska nad dorastajacym dzieckiem, Poznań 1984. 
Zatem obowiązek pielęgnowania więzi dziecka z jednym rodziców, które już nie mieszka w jednej wspólnocie domowej, występuje w innych porządkach prawnych $^{30}$. Wydaje się, że dopełnia to w ten sposób pewną triadę praw i obowiązków. Przede wszystkim zaś bierze pod uwagę sztandarową funkcję edukacyjno-prawna, jaką pełnią normy, które stopniowo wpływają i zmieniaja postępowanie członków rodziny, co związane jest ze zjawiskiem internalizacji norm, a więc procesu przekonania o normie będacej własnym standardem postępowania $^{31}$. Taka asocjacja aksjologiczna (a więc zgodność chronionych norm zewnętrznych z wartościami wewnętrznymi jednostki) prowadzi w efekcie do trwałej gotowości postępowania zgodnego z normami, a więc ustalenia postawy pronormatywnej ${ }^{32}$. Mając to na uwadze, również na płaszczyźnie przepisów poświęconych umożliwianiu przez jedno z rodziców kontaktu z dzieckiem drugiemu z nich naczelna powinna być rola propagujacca zamiast ustalajaca system sankcji. Zadaniem jej powinno być rozpowszechnianie idei swobodnego, nie zaś utrudnionego prawa do kontaktu.

Warto więc sformułować wniosek de lege lata co do istnienia takiego obowiązku, wynikającego z art. 113 k.r.o. Na jego podstawie wskazać należy, że rodzice mają prawo i obowiązek kontaktu z dzieckiem, zarówno względem dziecka, jak i względem siebie nawzajem, gdy żyją w rozłączeniu. Alternatywnie de lege ferenda można postulować dodanie przepisu precyzującego, aby przysługującemu jednemu z rodziców roszczeniu odpowiadał również obowiązek drugiego z rodziców do niezakłócania kontaktu. Nie tylko więc należy wywodzić je z prawidłowego wykonywania władzy rodzicielskiej, lecz sformułować niezależną podstawę prawną w ramach oddziału 3 poświęconego prawu i obowiązkowi kontaktu z dzieckiem.

\section{NATURALNY CHARAKTER INSTYTUCJI KONTAKTU}

Potrzeba kontaktu istniejacca pomiędzy członkami rodziny, szczególnie w relacji rodzice-dziecko, istnieje bez względu na to, czy więź taka już się wytworzyła czy jeszcze nie. Wniosek taki wysunać można z powszechnego zjawiska poszukiwania dzieci przez rodziców biologicznych, a także przez dzieci, które powzięły wątpliwość co do swego pochodzenia ${ }^{33}$. Jak podkreśla się w literaturze, „poszukiwanie przez dzieci adoptowane własnej tożsamości biologicznej: drzewa genealogicznego i biologicznych rodziców, pokazuje, że ludzka więź oparta jest na skłonnościach, które wynikają z biologii (instynkty), a które jednocześnie ją przekraczają" ${ }^{34}$.

${ }^{30}$ Tak np. w ustawodawstwie niemieckim, por. T. Justyński, Prawo..., s. 139-141.

${ }^{31}$ K. Pałecki, Prawoznawstwo - prawo w porzqdku społecznym, Warszawa 2003, s. 58.

${ }^{32}$ Ibidem, s. 70.

${ }^{33}$ Por. J. Zajączkowska, rec.: J. Gajda, Tajemnica przysposobienia $i$ jej ochrona $w$ polskim prawie cywilnym, Przemyśl-Rzeszów 2012, „Ruch Prawniczy, Ekonomiczny i Socjologiczny” 78, 2016, z. 1, s. 277-280.

${ }^{34}$ Z.N. Brzózy, Więź pomiędzy rodzicami a dzieckiem. Teologiczny kontekst problemu, Poznań 2009, s. 9 i pow. tam lit. 
W sposób najbardziej spójny i wyczerpujący zagadnienie naturalnego charakteru prawa do kontaktu przedstawione zostało przez doktrynę niemiecką. Większość jej przedstawicieli stoi na stanowisku, że prawo to jest konsekwencją naturalnego prawa rodziców (niem. Elternrecht) ${ }^{35}$. Niemiecki Federalny Trybunał Konstytucyjny (FTK) wielokrotnie już potwierdził powyższą tezę, dodając, że prawo do kontaktu podlega ochronie gwarantowanej przez art. 6 ust. 2 zd. 1 niemieckiej Konstytucji (Grundgesetz, dalej jako: GG) ${ }^{36}$. Twierdzi się też, że prawo do kontaktu jest naturalnym i niezbywalnym prawem rodzi$c^{c} w^{37}$. Prezentowane przez doktrynę niemiecką poglądy znajdują swą inspirację w art. 6 ust. 2 zd. 1 GG, którego brzmienie jest następujące: „Opieka oraz wychowanie dzieci stanowią naturalne prawo rodziców oraz ich priorytetowy obowiązek". Analogiczne rozważania w literaturze przedmiotu w Wielkiej Brytanii, USA czy w Izraelu pozwalają również na gruncie prawa polskiego szukać odpowiedzi na pytanie, czy wywodzace się z naturalnej więzi rodzicielskiej prawo do kontaktu ma prawononaturalną treść. Jeśli udzielić odpowiedzi twierdzacej, to prawo do kontaktu, wynikające $\mathrm{z}$ więzi rodzicielskiej, nie może zostać odebrane przez zgodę rodziców na przysposobienie, adekwatnie do trwajacego dalej prawa do poznania swojej tożsamości; tak też uznać by można, że dziecko ma również przyrodzone prawo do kontaktów. Jeśli przyjąć w pewnym sensie pośrednią koncepcję naturalistyczna, to mimo że prawo do kontaktu zostało skodyfikowane w prawie stanowionym, nie można by mu było odmówić jednocześnie pochodzenia prawnonaturalnego, zagwarantowanego przez konstytucje państwowe i powszechne deklaracje. W odróżnieniu jednak od stricte prawa naturalnego można by przyjąć, że jest ono prawem o charakterze naturalnym. Na wzór art. 6 ust. 2 GG, z którego część doktryny wywodzi pochodzenie prawa do kontaktu od prawa naturalnego, na gruncie prawa polskiego normatywną podstawę stanowić może odwołanie się do art. 30 Konstytucji RP ${ }^{38}$. Przyjęto bowiem, że godnośćc ${ }^{39}$ jest prawem niezbywalnym, przyrodzonym i naturalnym ${ }^{40}$. Z kolei z ugruntowanej idei dotyczacej godności płynie prawo do poznania informacji o swoim pochodzeniu ${ }^{41}$. Jak się podkreśla, tożsamość biologiczna istoty ludzkiej i jej godność stanowią niero-

${ }^{35}$ F. Hönig, Das Umgangsrecht im Spannungsfeld zwischen Eltern- und Kinderrechten unter besonderer Berücksichtigung der verfassungsrechtlichen Problematik, Hamburg 2004, s. 157.

${ }^{36}$ BVerfGE 64, 180(188) = FamRZ 1983, s. 872(873); BVerfGE 31, 194(206) = FamRZ 1971, s. 421(424); BVerfG FamRZ 1995 1993, s. 622-663.

${ }^{37}$ S. Kappler, T. Kappler, Handbuch Patchworkfamilie, Einbeck 2013, s. 90.

${ }^{38}$ Tak W. Skrzydło: „Do koncepcji tej [prawnonaturalnej] nawiązuje polski ustrojodawca w dwojaki sposób, po pierwsze przyjmując regulacje międzynarodowe wywodzące się z tych właśnie koncepcji, po drugie, stwierdzając istnienie "przyrodzonej i niezbywalnej godności człowieka», która stanowi "źródło wolności i praw człowieka i obywatela«" (idem, Konstytucja Rzeczypospolitej Polskiej. Komentarz, Lex/el. 2013).

${ }_{39}$ Zob. M. Borski, Godność człowieka jako wartość uniwersalna, „Przegląd Prawa Publicznego" 2014, nr 3, s. 7 i n.

${ }^{40}$ Por. szerzej B. Banaszak, Porównawcze prawo konstytucyjne wspótczesnych państw demokratycznych, Lex/el. 2012.

${ }^{41}$ Por. szerzej L. Bosek. Prawo osobiste do poznania wtasnej tożsamości biologicznej, „Kwartalnik Prawa Prywatnego" 17, 2008, z. 4, s. 947 i n. 
zerwalna jedność ${ }^{42}$. Prawo do informacji o swoich korzeniach jako część prawa do tożsamości już dawno zostało uznane za międzynarodowe prawo człowieka. Artykuł 8 Konwencja praw dziecka chroni prawo do zachowania tożsamości, $\mathrm{w}$ tym relacje rodzinne poza bezprawną ingerencja, art. 7 zaś stanowi prawo, aby znać i być wychowywanym przez rodziców ${ }^{43}$.

Można by zatem przyjąć, że skoro kontakt służy wzajemnemu poznaniu, to wywodzić można prawo do tego kontaktu z prawa do poznania swojej tożsamości. W takim kształcie byłoby to prawo o charakterze naturalnym, które jednak ma również swoje źródło normatywne stwierdzone w Konstytucji.

\section{DOMNIEMANIE PRAWA I OBOWIĄZKU KONTAKTU}

Konsekwencją uznania, że prawo do kontaktu jest przyrodzone i ma charakter naturalny powinno być założenie istnienia domniemania. Dla przykładu warto powołać prawo rodziców do odebrania dziecka od osoby, która je bezprawnie zatrzymała. Nawet gdyby okoliczności świadczyły przeciwko odebraniu dziecka, a także gdyby samo dziecko oponowało przeciwko temu odebraniu - dopóki rodzice nie zostali pozbawieni władzy rodzicielskiej, działa domniemanie, że $\mathrm{w}$ interesie dziecka $\mathrm{i}$ zgodnie $\mathrm{z}$ jego dobrem jest, aby pozostawało ono w zasięgu władzy swoich rodziców ${ }^{44}$. Podobnie uzasadnione byłoby stwierdzenie, że domniemanie kontaktu jako prawo przyrodzone dziecka jest co do zasady zgodne z jego dobrem. Skutkowałoby to przyjęciem, że skoro kontakt z dzieckiem stanowi prawo o charakterze naturalnym, rodzice nie powinien ubiegać się o przyznanie go, lecz wprost przeciwnie. To z rodziców, które domaga się ograniczenia tego prawa, powinno udowodnić przemawiające za tym przesłanki, nie zaś drugie z rodziców wnoszace o przyznanie go, co zapobiegłoby szerzacym się na tle sporów sądowych antagonizmom. Taka linia rozważań prowadzi do przyjęcia, że w modelowym kształcie prawo i obowiązek kontaktu są pełne i niezakłócone, a więc istnieją naturalnie w jak najszerszej postaci, po części na wzór sprawowania pieczy nad osobą dziecka. W takim rozumieniu prawo i obowiązek kontaktu z art. 113 k.r.o. stanowi instytucję regulującą naturalną więź i relację rodzicielska, nie zaś ustalającą i przyznającą to prawo.

\section{OCHRONA WIĘZI NATURALNEJ}

W kontekście poczynionych uwag wydaje się, że ustawodawca majacy chronić naturalną więź rodzicielską nie powinien konstruować koncepcji o nieistnieniu prawa, które płynie z natury człowieka i de facto przysługuje z samej

42 O. Nawrot, Naturalizacja prawa w kontekście rozwoju biologii i medycyny, „Forum Prawnicze" 2015, nr 6(32), s. 7 i powołana tam literatura.

${ }^{43}$ C. Fenton-Glynn, Information on origins: right or obligation?, „Family Law” 46(8), 2016, s. 947 .

${ }^{44}$ J. Sauk, op. cit., s. 17. 
natury rzeczy, a więc z faktu istnienia owej więzi rodzicielskiej. W świetle normy wyrażonej w art. $119^{1} \S 1$ k.r.o. wykluczona została możliwość dalszego istnienia omawianego prawa nie przez stwierdzenie niemożności dalszej jego realizacji, lecz przez ustalenie nieprzysługiwania prawa do kontaktu. Tymczasem, jak się wydaje, właściwsze byłoby przyjęcie, że prawo to, skoro ma charakter naturalny, nie może być wykonywane, a zatem zakazać można rodzicom biologicznym poszukiwania i dochodzenia kontaktu $\mathrm{z}$ dzieckiem ${ }^{45}$. Całkowicie odmienne jest bowiem brzmienie normy, która stanowi o zakazie kontaktu bądź niewykonywaniu kontaktu niż o nieprzysługiwaniu prawa do kontaktu.

Odwołując się do klauzuli dobra dziecka, nie zawsze kontakt z rodzicami biologicznymi będzie wbrew temu dobru, co nie wyłącza możliwości pozostawienia „przestrzeni” dla tych sytuacji, kiedy kontakt ten byłby z nim zgodny. Dlatego właśnie norma dotycząca kontaktów nie powinna stwierdzać ich nieistnienia czy nieprzysługiwania, lecz określać w sposób powinnościowy słuszne wobec ogólnych paradygmatów postępowanie rodziców biologicznych. Co więcej, nie ulega już wątpliwości, że dziecko ma w tym przedmiocie własne prawo podmiotowe, powiązane z jego prawem do godności i prawem do poznania swojego pochodzenia, również za cenę naruszenia ochrony prywatności rodziców, z drugiej zaś strony nie ma ono pełnej możliwości realizowania swego roszczenia. Dlatego té̇ jeśli miałoby ono potrzebę nawiązania i utrzymywania kontaktu z rodzicami biologicznymi (przy np. równoczesnym braku wytworzenia się więzi z rodzicami adopcyjnymi ${ }^{46}$ ) i spotkałaby się ona z adekwatna potrzebą po stronie tychże rodziców, to w takich okolicznościach i zgodnie z dobrem dziecka byłoby to możliwe, gdyby norma art. $119^{1}$ k.r.o. nie wskazywała na nieprzysługiwanie rodzicom prawa do kontaktu, a jedynie na czasowy jego zakaz. Ponadto dziecko wysłuchane na tę okoliczność mogłoby również wyrazić chęć ustalenia kontaktów, jeszcze zanim osiagnie pełnoletnośćc ${ }^{47}$.

W literaturze zagranicznej podkreśla się, jak bardzo dążenie do uzyskania informacji o oddanym do adopcji dziecku bądź takiego dziecka o rodzicach biologicznych, determinuje życiowy cel i jak częsta jest satysfakcja z odnalezienia i nawiązania wzajemnego kontaktu ${ }^{48}$. Zasadniczy argument odnosi się do wszechobecnej wirtualnej rzeczywistości, która sprawiła, że instytucja przysposobienia została nieodwracalnie zmieniona przez portale społecznościowe i powszechny dostęp do Internetu. Strony takie jak Facebook (skupiające ok. 1,65 miliarda internatów), na których tworzą się lokalne grupy zrzeszające poszukujących rodziców i poszukujących dzieci, umożliwiają wzajemne odnalezienie się rodzin biologicznych, czego konsekwencja staje się potajemne utrzymywanie przez nie kontaktów, często z małoletnim dzieckiem.

${ }^{45}$ T. Sokołowski, w: H. Dolecki, T. Sokołowski (red.), Kodeks rodzinny i opiekuńczy. Komentarz, Warszawa 2013, s. 843.

46 Ibidem, s. 844.

${ }^{47}$ Por. szerzej o instytucji wysłuchania: J. Zajączkowska, Głos dziecka na wokandzie - o instytucji wystuchania małoletniego, „Palestra” 58, 2013, nr 7-8, s. 56 i n.

48 E.J. Samuels, The strange history of adult adoptee access to original birth records, „Adoption Quarterly" 5(2), 2001, s. 64. 


\section{ZAWIESZENIE WYKONYWANIA KONTAKTÓW}

Wobec ugruntowania się $\mathrm{w}$ aspekcie procesowym zawieszenia wykonywania kontaktów, głównie w sądowym postępowaniu zabezpieczającym, należy rozważyć potrzebę wprowadzenia podstawy materialnoprawnej. Przede wszystkim instytucja taka wskazywałaby na tymczasowość nieutrzymywania kontaktów wobec przemijającej przeszkody i automatyczny powrót do niezmienionych stosunków w rodzinie. Ponadto stanowiłoby to pojęcie neutralne i niewskazujące na zagrożenie dobra dziecka wśród przesłanek, co zapobiega generowaniu sytuacji konfliktowych. Dzięki wprowadzonej instytucji byłoby jasne, że uprawnienia i obowiązki zostają wyłączone czasowo bez negatywnej konotacji zakazu czy ograniczenia w prawach i gwarantuja obiektywność. Może to również niejednokrotnie zapobiec pewnym nieodwracalnym skutkom ingerencji. Orzeczenia ograniczające prawo do wzajemnego kontaktu zarówno rodziców, jak i dziecka mogą w sposób zrozumiały zniechęcić do powrotu i podtrzymania wcześniejszej relacji. Innymi słowy, konsekwencją stosowania dotychczasowych przesłanek ograniczających na płaszczyźnie psychologicznej może być osłabienie zainteresowania dzieckiem. Jeśli przyjąć jednak, że prawo do kontaktu ma charakter naturalny, to uznać należy właściwość nie zawieszenia prawa do kontaktu, lecz zawieszenia jego wykonywania. Nie bez znaczenia przy tym pozostaje również zawieszenie władzy rodzicielskiej, bynajmniej niepociagające za sobą automatycznie zawieszenia kontaktów wobec niezależności obu instytucji.

\section{KONTAKT Z DZIECKIEM W RODZINIE PEENEJ}

W świetle art. 113 k.r.o. niezaprzeczalne jest, że ustawodawca nie uznał kontaktu za element władzy rodzicielskiej. Dlatego istotna kwestia pozostaje rozstrzygnięcie, czy prawo i obowiązek kontaktu pozostają pod odrębną ochroną w przypadku rodziny pełnej. Wzajemna zależność instytucji władzy rodzicielskiej i kontaktów sprawia, że przyjać można, iż kontakt w przypadku rodziny funkcjonującej prawidłowo nie istnieje wcale, co z kolei stoi w sprzeczności z normatywnie określoną przez ustawodawcę odrębnością. Przepis art. 113 k.r.o. sugerować może, że prawo i obowiązek kontaktu istnieją również w rodzinie pełnej. Bez względu jednak na wzajemne powiązania obu instytucji, szczególnie zaś zawieranie się zachowań definiujących instytucję kontaktu w pieczy nad osobą dziecka, wspomniany charakter naturalny kontaktu sprawia, że przyjąć należy, iż prawo takie istnieje. Nie oznacza to jednak, że w prawidłowo funkcjonującej rodzinie powinno ono być wyróżniane i osobno chronione, gdyż powodowałoby to przysługiwanie rodzicom sprawującym władzę rodzicielską dwóch równoległych bądź nawet konkurencyjnych podstaw prawnych ${ }^{49}$.

${ }^{49}$ Por. P. Mostowik, Kontakty matki i ojca z dzieckiem jako treść władzy rodzicielskiej, w: M. Nazar (red.), Prawo cywilne - stanowienie, wyktadnia $i$ stosowanie: ksiega pamiatkowa dla 
Uznaniu, że instytucja kontaktów jest wyodrębniona w trakcie sprawowania władzy rodzicielskiej, zapobiega przyjęcie konstrukcji zakładające, że prawo do kontaktu, będąc pod niezależną prawną ochrona, pozostaje niejako „uśpionym" roszczeniem, które aktualizuje się dopiero w momencie rozpadu rodziny. W tej koncepcji uznać można, że prawo do kontaktu istnieje, pozostaje nawet pod ochrona, lecz nie stanowi przedmiotu wyodrębnienia, które powodowałoby konkurencyjność praw wynikających z obu instytucji. Konstrukcja taka wyklucza zatem wspólistnienie kontaktu i władzy rodzicielskiej i zapobiega tym samym dostrzeganiu kolizji praw, które de facto przecież zawierają się w sobie. $\mathrm{Z}$ drugiej jednak strony przez wzgląd na charakter naturalny prawa do kontaktów nie można uznać, że prawo to w danym momencie zupełnie nie istnieje.

Zestawienie omawianej instytucji z obowiązkiem alimentacyjnym pozwala dostrzec podobnie funkcjonujący mechanizm. Otóż zgodnie z utrwalona w orzecznictwie zasada, dzieci mają prawo do równej stopy życiowej z rodzicami zarówno wtedy, gdy mieszkaja wspólnie z nimi, jak i wówczas, gdy mieszkaja oddzielnie. Jednakże do czasu, gdy rodzina funkcjonuje jako „pełna”, trudno założyć, że małoletni będzie korzystał z prawa do równej stopy życiowej w sytuacji, kiedy jego potencjalne roszczenie jest zaspokajane w ramach obowiąku pieczy nad dzieckiem, wynikającej z władzy rodzicielskiej i obowiązku zaspokajania potrzeb rodziny. Roszczenie zatem „uaktywnia się” i jest dochodzone dopiero w momencie rozpadu rodziny.

Warto w tym miejscu wspomnieć o koncepcji tzw. potencjalnego obowiąz$\mathrm{ku}$ alimentacyjnego ${ }^{50}$, który pojawia się wraz z powstaniem stosunku rodzinnoprawnego, i o skonkretyzowanym obowiązku i roszczeniu. Zgodnie z nia wyróżnia się konkretny obowiązek alimentacyjny uzależniony od zaistnienia przesłanek, w związku z którym uprawniony ma roszczenie oraz potencjalny obowiązek alimentacyjny polegajacy na istnieniu tylko stosunku rodzinnoprawnego, będącego źródłem roszczenia ${ }^{51}$.

Jeżeli spojrzeć przez pryzmat wykładni teleologicznej, należy uznać, że zamierzeniem ustawodawcy z całą pewnością nie było wydzielanie kontaktu z obszaru pieczy nad osobą dziecka w sytuacji poprawnie funkcjonujaccej rodziny. Uznanie całkowitej niezależności obu instytucji przyczyniłoby się do niemożności oceniania wykonywania władzy rodzicielskiej przez pryzmat kontaktów, co jest szczególnie widoczne w przypadku tzw. pieczy dzielonej w sytuacji, gdy dziecko pozostaje pod opieką osób sprawujących pieczę zastępczą. Podczas analizy potrzeby zsynchronizowania kontaktów z wykonywaniem władzy rodzicielskiej nasuwa się następująca refleksja: uznając, że nieutr zy my w a nie kontaktów z dzieckiem mieści się w pojęciu „trwałego nieinteresowania się dzieckiem", a to stanowi przesłankę pozbawienia władzy rodzicielskiej, to posługując się wykładnią a contrario, utrzy mywanie tych kontaktów z ko-

uczczenia setnej rocznicy urodzin Profesora Jerzego Ignatowicza, Lublin 2015, s. 257-270; idem, Kontakty dziecka $z$ rodzicami, krewnymi $i$ bliskimi a władza rodzicielska, „Przegląd Sądowy” 2013, nr 3, s. 7-36.

${ }^{50}$ T. Smyczyński, w: System prawa prywatnego, t. 11: Prawo rodzinne i opiekuńcze, Warszawa 2011 , s. 755 .

${ }^{51}$ Ibidem. 
lei mieści się w pojęciu interesow ania się dzieckiem jako przejawu prawa i obowiązku wynikającego z władzy rodzicielskiej. Tym sposobem skoro niewypełnianie obowiązków związanych z kontaktem oznacza niewypełnianie obowiązku wynikającego z władzy rodzicielskiej, to analogicznie wypełnianie tych obowiązków wynikających z pierwszej z instytucji musi oznaczać wypełnianie obowiązów zarazem z tej drugiej.

Innymi słowy, wobec jednego z rodziców sprawującego władzę rodzicielska przyjmowanie istnienia odrębnego prawa i obowiązku kontaktu razi niezaprzeczalną sztucznościa. Dlatego też uznać można, że prawo takie i obowiązek istnieja, lecz - posługując się pewną fikcją prawną - stanowi ono roszczenie uśpione, które potencjalnie ulec może aktualizacji, do tego jednak momentu nie stanowi ono wyszczególnionego bytu równolegle istniejącego, czy też konkurencyjnego wobec władzy rodzicielskiej. W przeciwnym wypadku mogłoby to uzasadniać pogląd o występowaniu dwóch różnych podstaw prawnych przysługiwania prawa do kontaktu w odniesieniu do tego z rodziców, które sprawuje władzę rodzicielska, gdzie pierwszym źródłem tego prawa jest rzeczona władza, drugim zaś - stosunek bliskości z dzieckiem (więzi emocjonalne) ${ }^{52}$. Argumentem wysuwanym na poparcie wspomnianego stanowiska jest przytaczany w tym kontekście art. $120^{1}$ k.r.o., wskazujacy na kandydatów na rodziców przysposabiających, w czym upatruje się poszerzenie zakresu podmiotowego istniejącego w art. $113^{6}$ k.r.o. ${ }^{53}$ Pogląd ten nie wydaje się jednak słuszny, gdyż dotyczy innej instytucji prawnej. Okres osobistej styczności z art. $120^{1}$ k.r.o., którego celem jest sprawdzenie dobrania emocjonalnego stron potencjalnej adopcji, ma charakter tymczasowy i celowy. Ponad wszystko zaś stosunek prawny zastępujący stosunek rodzicielski powstaje dopiero po przysposobieniu, a okres osobistej styczności dotyczy momentu, zanim to nastapi ${ }^{54}$. Tymczasem instytucja kontaktu ma nie tylko charakter ciagły, lecz także stanowi pośrednio substytut atrybutu władzy rodzicielskiej w postaci pieczy nad osoba dziecka (z odpowiednim, a więc niejako pochodnym prawem innych niż rodzice osób). Co więcej, taki kontakt powinien dla dobra relacji ulegać stopniowemu poszerzaniu i ewolucji. Cele obu instytucji są zatem odmienne i nie należy wyciagać wniosków mających wpływ na relację kontaktu z władzą rodzicielska z normy dotyczacej przysposobienia.

\section{PRAWO DO KONTAKTU PREADOPCYJNEGO}

Należy podkreślić, że pojęcie „kontakt” jest nietożsame i niezamienne z pojęciem „osobista styczność”, a pozostawienie w k.r.o. drugiego z nich nie wynika z „przeoczenia ustawodawcy”55. Odnosi się ono bowiem do instytucji

52 Por. M. Grudzińska, op. cit., s. 20.

53 Tak J. Strzebińczyk, w: System prawa prywatnego, t. 12: Prawo rodzinne i opiekuńcze, Warszawa 2011, s. 386.

54 T. Sokołowski, Prawo rodzinne. Zarys wykładu, Poznań 2010, s. 178.

55 Tak np. J. Strzebińczyk, w: System prawa prywatnego, t. 12: Prawo rodzinne i opiekuńcze, s. 374 
związanej z przysposobieniem i jest etapem powstawania więzi rodzicielskiej, majaccej na celu wzajemny dobór stron tej relacji, nie stanowi zaś instytucji na wzór prawa i obowiązku z art. 113 k.r.o. Instytucja kontaktu ma na celu podtrzymanie więzi, która już wcześniej z reguły istniała, a nie jej stworzenie (choć takiego przypadku nie można również wykluczyć). Odmienny cel, a także czas trwania obu instytucji uniemożliwia zamienne ich traktowanie. Z tego względu zastanawiające jest posługiwanie się pojęciem „kontakt” w ustawie z 9 czerwca 2011 r. o wpieraniu rodziny i systemie pieczy zastępczej ${ }^{56}$. Ustawodawca bowiem konsekwentnie odwołuje się do pojęcia kontaktu, a nie osobistej styczności w opisywaniu tej instytucji w kontekście przysposobienia. W ustawie tej nie sposób odnaleźć drugiego ze wspomnianych pojęć. Tytułem przykładu art. 169 ust. 1 u.w.r.s.p.z. wskazuje, że ośrodek adopcyjny umożliwia kontakt z dzieckiem oraz udostępnia o nim informacje kandydatom do przysposobienia dziecka po ukończeniu przez nich szkolenia ${ }^{57}$. Przepis ten pozostaje w ścisłym związku z art. $120^{1}$ k.r.o. stanowiącym o okresie osobistej styczności, zanim nastapi przysposobienie, a więc traktuje także o kandydatach na rodziców adopcyjnych. Równocześnie jednak styczność z art. $120^{1}$ k.r.o. nie jest tożsama z kontaktem $\mathrm{z}$ art. 113 i n. k.r.o. W istocie jej zakres podmiotowy jest całkowicie odmienny, gdyż nie należy utożsamiać czasu spędzanego z osoba bliską z kandydatem na taką osobę. Nie tylko ustawa posługuje się terminem „kontakt” wówczas, gdy de facto odnosi się do instytucji osobistej styczności w okresie przedadopcyjnym. Pojęcie to zamiennie stosowane jest w kontekście utrzymania kontaktu zarówno z rodzicami naturalnymi, jak i kandydatami na rodziców adopcyjnych. Co więcej, w ustawie nie występuje pojęcie osobistej styczności, posługuje się ona jedynie pojęciem kontaktu. Innymi słowy, pojęcie kontaktu, które występuje we wspomnianej ustawie i która to odsyła do art. $120^{1}$ k.r.o., nie stanowi kontaktu w rozumieniu art. 113 k.r.o. Jednakże wobec zbieżnego sposobu realizacji przy orzekaniu o osobistej styczności należy dopuszczać korzystanie z form kontaktu zawartych w katalogu art. 113 $\S 2$ k.r.o.

\section{WNIOSKI KOŃCOWE}

Z zaprezentowanych rozważań wynika, że kontakt - pomimo ustawowego obustronnego prawa i obowiązku prima facie zbliżajacego instytucję tę do tych o charakterze zobowiązaniowym - ma w istocie charakter rodzinnoprawny. W konsekwencji zarówno roszczenie, jak i sankcja z tytułu niewykonywania prawa i obowiązku przyjmują również charakter rodzinnoprawny.

Prawo do kontaktów cechuje również charakter naturalny wynikajacy z więzi rodzicielskiej. Przysługuje ono rodzicom oraz dziecku z samej natu-

${ }^{56}$ Ustawa z 9 czerwca 2011 r. o wspieraniu rodziny i systemie pieczy zastępczej, Dz. U. 2011, Nr 149, poz. 887 ze zm. (dalej jako: u.w.r.s.p.z.).

57 Art. 169 ust. 1 zmieniony przez art. 3 pkt 2 ustawy z 24 lipca 2015 r. (Dz. U. 2015, poz. 1199 ze zm.) zmieniającej m.in. ustawę z dniem 18 września 2015 r. 
ry i uzyskuje - w ujęciu modelowym - szeroki, wręcz nieograniczony kształt. Przepisy normujące kontakt rodziców z dzieckiem stanowią więc pewne ograniczenie pierwotnie przysługującego nieograniczonego prawa do kontaktu, które istnieje od chwili powstania więzi rodzicielskiej.

Konsekwencją charakteru prawnonaturalnego jest istnienie domniemania prawa do kontaktu jako zgodnego z dobrem dziecka, przy czym domniemanie to nie dotyczy innych niż rodzice i dziecko osób przez wzgląd na ochronę instytucji władzy rodzicielskiej. Charakteru naturalnego nie ma również pokrewna do kontaktów instytucja „osobistej styczności” orzekana w okresie preadopcyjnym. Pomimo możliwości przyjęcia, że należy przy jej stosowaniu korzystać z form przewidzianych w art. 113 § 2 k.r.o., nie można uznać jej za instytucję tożsamą z kontaktem również z racji niemożności występowania obowiązku po stronie kandydatów na przysposabiających.

Mając na względzie istnienie cechy charakteru naturalnego, prawo i obowiązek kontaktu nie wygasają ani nie ustają. Skoro bowiem wynikają one z więzi rodzicielskiej, to trwają tak dopóty, dopóki trwa ta więź. Z uwagi na brak określenia przez ustawodawcę końcowej granicy prawa i obowiązku utrzymywania kontaktów, uzasadnione jest przyjęcie dalszego ich trwania, co stanowi również konsekwencję odmiennego ukształtowania pokrewnej instytucji władzy rodzicielskiej (analogicznie natomiast do trwającego przez całe życie obowiązku szacunku i wspierania się z art. 87 k.r.o.). Nie można również skutecznie przyjaćc, że prawo do kontaktu „nie przysługuje”, a jedynie stwierdzić można ograniczenie lub zakaz jego wykonywania, stanowiace $\mathrm{w}$ istocie ingerencję $\mathrm{w}$ jego pełen kształt. Dlatego uwzględniajac charakter kontaktu, zarówno naturalny, jak i osobisty, który to kontakt przysługuje rodzicom i dziecku w imię łączącej ich więzi naturalnej, należy rozważyć, czy ustawodawca powinien stwierdzać, że kontakt ten w przypadku przysposobienia całkowitego ze wskazaną w ustawie chwilą przestaje przysługiwać. Uważa się, że blisko połowa wszystkich osób adoptowanych w USA poszukuje swoich biologicznych rodziców i dąży do spotkania z nimi ${ }^{58}$. Dzięki zaś wspomnianym wcześniej portalom internetowym kontakt ten coraz częściej staje się społecznym faktem. Od wywiedzionego z godności prawa do poznania tożsamości biologicznej, a co za tym idzie - rozumienia swoich korzeni, wiedzy o rodzeństwie i rodzicach biologicznych, niedaleko już do niezbywalnego prawa do kontaktu. Tym bardziej że chodzi w istocie o niemożność dochodzenia kontaktów z dzieckiem, nie zaś o stwierdzenie ich nieistnienia.

Charakter prawa i obowiązku występuje także z różnym natężeniem po stronie rodziców i dzieci, najpierw po stronie rodziców, gdy stanowi bardziej ich obowiązek, potem zaś prawo. Z kolei po stronie dziecka w większym stopniu początkowo jest prawem, wraz ze starzeniem się rodziców - jego obowiązkiem. Dlatego tė̇ przyjąć można istnienie swoistej „relacji zmiennej” („obrotowej”) prawa i obowiązku rodziców oraz dziecka, tym bardziej że względem małego dziecka obowiązek ten musi być słabszy niż wobec rodziców, co wynika z braku stosowania wobec dziecka sankcji, nawet o charakterze pośrednim,

${ }^{58}$ R. Giryńska, Problemy jawności adopcji, w: K. Ostrowska, E. Milewska (red.), Adopcja, teoria i praktyka, Warszawa 1999, s. 168. 
w przeciwieństwie do możliwości oceny zachowań rodziców (skutkować może ingerencją we władzę rodzicielska). Przy czym dla właściwej realizacji kontaktów ustalić trzeba odpowiedni obowiązek rodziców ich niezakłócania, tworzący „triadę" praw i obowiązków należycie zabezpieczającą relację dziecka z uprawnionym do kontaktów jednym z rodziców.

Trzeba również przyjąć, że wyodrębnienie instytucji kontaktu z władzy rodzicielskiej dotyczy jedynie sytuacji niesprawowania pieczy nad osoba dziecka, tj. wynikającej z drugiej z nich, dlatego uznać można, że prawo i obowiązek kontaktu w rodzinie pełnej przyjmuje postać uśpionego roszczenia, które aktualizuje się dopiero w momencie rozpadu rodziny. W okresie poprzedzajacym rozpad - wobec niemożności sprawowania wspomnianej pieczy bez zachowań stanowiących równocześnie formy kontaktu - nie występuje osobne prawo i obowiązek kontaktu z art. 113 k.r.o. Przeciwne założenie upoważniałoby do przyjęcia poglądu o dwóch równoległych i konkurencyjnych uprawnieniach rodziców sprawujących na co dzień pieczę - jednego z art. 113 k.r.o., drugiego z art. $95 \S 1$ k.r.o. ${ }^{59}$

Podsumowując, należy również zauważyć, że w kontekście utrzymywania kontaktów z dzieckiem nie bez znaczenia jest postępująca informatyzacja społeczeństwa. Są to procesy do tego stopnia rozwinięte, że przykładowo amerykańskie orzeczenia w sprawach dotyczących kontaktów z dzieckiem zaczęły stosować termin „wirtualna wizyta”, określając w ten sposób komunikację za pośrednictwem Skype'a i podobnych mu programów ${ }^{60}$, stanowiących nie tylko formę pomocniczą kontaktów, lecz także substytut spotkań. W taki oto sposób instytucja kontaktu nabiera całkowicie nowego ksztaltu - umożliwia przykładowo pomaganie dziecku przy odrabianiu lekcji czy spotkanie z dziadkami, którzy podejdą podczas rozmowy ich syna do ekranu komputera, aby przywitać się z wnukiem. Jednakże zrodziło to kolejny problem - zastępowania kontaktu osobistego „e-kontaktem”"61, na który zwraca się uwagę wobec powstających współcześnie ustaw stanowych, regulujących prawo do kontaktu wirtualnego ${ }^{62}$. Również dla polskiej nauki i judykatury oznacza to perspektywę dalszych przemian oraz wyzwań wskazujących na nowe i nieodkryte kierunki badań w aspekcie omawianej instytucji kontaktów z dzieckiem.

dr Joanna Zajaczkowska

Uniwersytet im. Adama Mickiewicza w Poznaniu

joanna.zajaczkowska@lexfamilia.pl

\footnotetext{
${ }^{59}$ Por. szerzej T. Justyński, Prawo..., s. 119-120.

${ }^{60}$ R. Wolman, R. Pomerance, Telepresence technology in divorce and separation, „Open access Journal of Forensic Psychology" 4, 2012, s. 53.

${ }^{61} \mathrm{Na}$ wzór użytego określenia „e-visitation” w: W.P. Statsky, Family Law, New York 2013, s. 401.

${ }^{62}$ Pierwszym ze stanów w 2004 r. był stan Utah, obecnie są to również Floryda, Teksas i Wisconsin, por. szerzej: R. Wolman, R. Pomerance, op. cit., s. 53.
} 


\section{LEGAL ASPECTS OF CONTACT WITH A CHILD}

\section{Sum mary}

The article presents an analysis of the institution of contact with a child, which is a relatively new regulation in family law. Theoretical and legal considerations are intended to determine the legal nature of such contacts and show that they are of a family and personal nature. The mutual right and duty to have contact including the claim on the part of a child were also examined, as well as the concept of the contact itself, especially with regard to the parallel concept of a personal contact. At the same time, the institution of personal contact that appears in the adoption process was discussed. The article presents the idea of the necessity of establishing an obligation for one of the parents living with the child not to break contact with the child, as well as the idea of introducing an institution for suspending contacts. With regard to one parent holding parental authority, it is assumed that contact with a child takes the form of a dormant claim, which comes into effect when the family breaks up. The conclusions are therefore intended to provide an interpretation of the provisions of Articles $113-113^{6}$ and $119^{1}$ of the Family and Guardianship Code, which means that the considerations presented in this article are also of practical importance for maintaining contacts with a child. 
